\title{
Direct Grout Stabilization of High Cesium Salt Waste: Salt Alternative Phase III Feasibility Study
}

by

C. A. Langton

Westinghouse Savannah River Company

Savannah River Site

Aiken, South Carolina 29808

This paper was prepared in connection with work done under the above contract number with the U.S.

Department of Energy. By acceptance of this paper, the publisher and/or recipient acknowledges the U.S. Government's right to retain a nonexclusive, royalty-free license in and to any copyright covering this paper, along with the right to reproduce and to authorize others to reproduce all or part of the copyrighted paper. 


\section{DISCLAIMER}

Portions of this document may be illegible in electronic image products. Images are produced from the best available original document. 


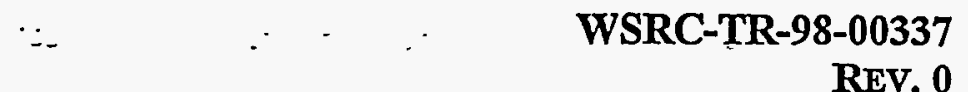

KEY WORDS: Saltstone

Cesium

Salt Waste Treatment

RETENTION: Permanent

DIRECT GROUT STABILIZATION OF HIGH CESIUM SALT WASTE:

SALT WASTE ALTERNATIVE PHASE II FEASIBILITY STUDY (U)

\author{
Author \\ Christine A. Langton, \\ Westinghouse Savannah River Company \\ Savannah River Technology Center, \\ Aiken, SC 29808
}

Date: September 30, 1998

Westinghouse Savannah River Company

Savannah River Site

Aiken, SC 29808

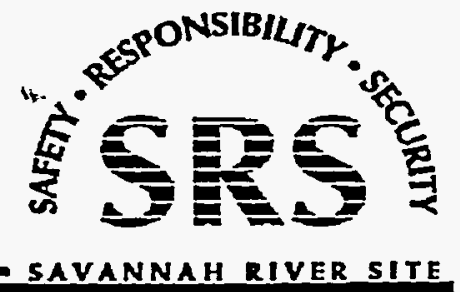


WSRC-TR-98-00337

Revision: 0

September 30, 1998

REVIEWS and APPROVALS

Author

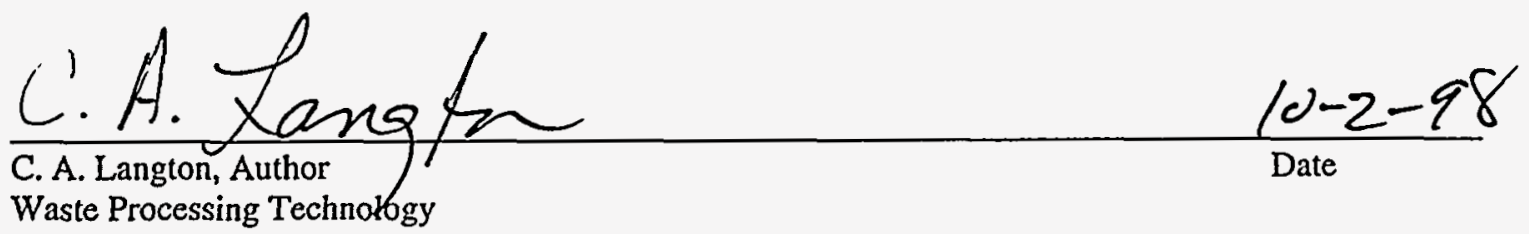

Approvals/Review

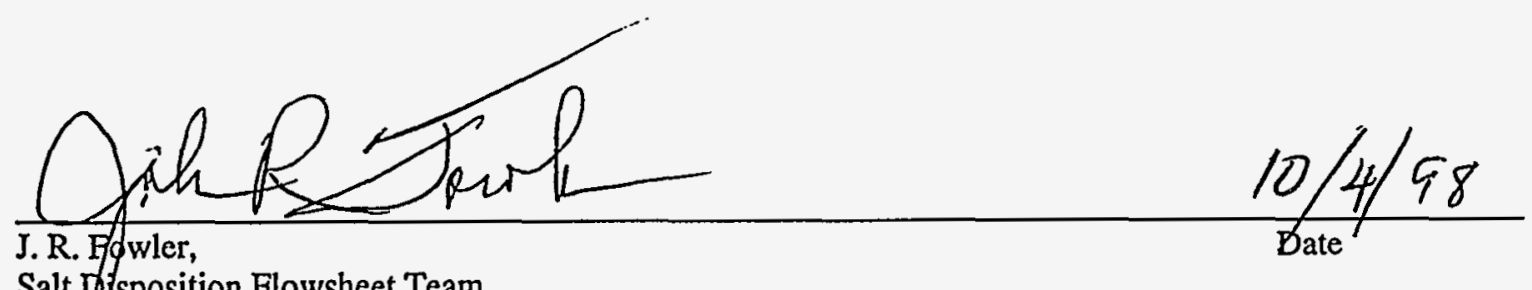

Salt If position Flowsheet Team

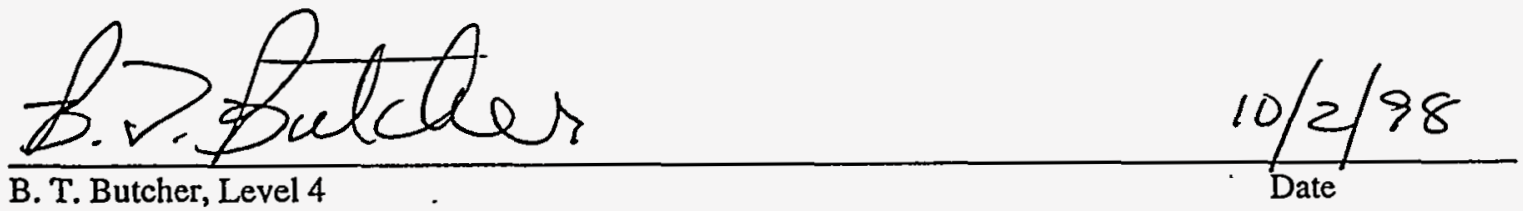

Waste Processing Technology

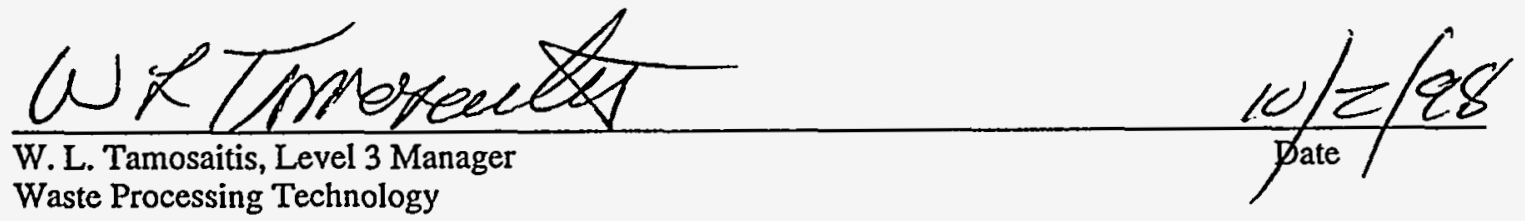

Waste Processing Technology

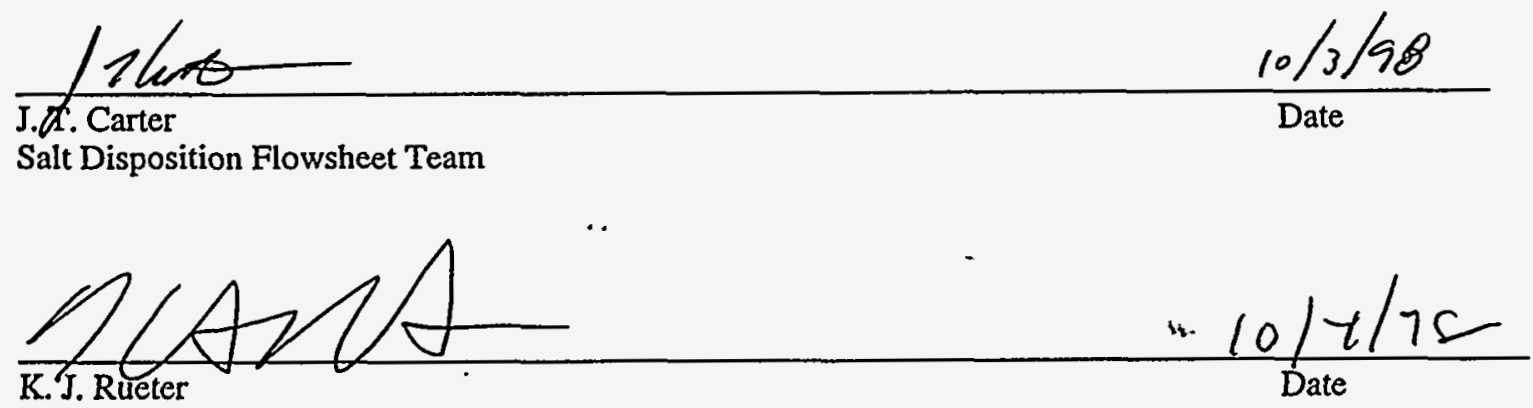

Salt Disposition System Engineering Team

2 
WSRC-TR-98-00337

Revision: 0

September 30, 1998

\title{
DIRECT GROUT STABUIZATION OF HIGH CESTUM SALT WASTE: SALT WASTE ALTERNATIVE PHASE II FEASIBILTTY STUDY (U)
}

\author{
Christine A. Langton, \\ Westinghouse Savannah River Company \\ Savannah River Technology Center, \\ Aiken, SC 29808
}

\section{SUMMARY}

The direct grout alternative is a viable option for treatment/stabilization and disposal of salt waste containing $\mathrm{Cs}-137$ concentrations of $1-3 \mathrm{Ci} / \mathrm{gal}$.

The composition of the direct grout salt solution is higher in sodium salts and contains up to a few hundred ppm Cs-137 more than the current reference salt solution. However it is still similar to the composition of the current reference salt solution. Consequently, the processing, setting, and leaching properties (including TCLP for $\mathrm{Cr}$ and $\mathrm{Hg}$ ) of the direct grout and current saltstone waste forms are very similar.

The significant difference between these waste solutions is that the high cesium salt solution will contain between 1 and 3 Curies of $\mathrm{Cs}-137$ per gallon compared to a negligible amount in the current salt solution. This difference will require special engineering and shielding for a direct grout processing facility and disposal units to achieve acceptable radiation exposure conditions. The $\mathrm{Cs}-137$ concentration in the direct grout salt solution will also affect the long-term curing temperature of the waste form since 4.84 Watts of energy are generated per $1000 \mathrm{Ci}$ of Cs-137. The temperature rise of the direct grout during long-term curing has been calculated by A. Shaddy, SRTC. ${ }^{1}$

The effect of curing temperature on the strength, leaching and physical durability of the direct grout saltstone is described in this report. At the present time, long term curing at $90^{\circ} \mathrm{C}$ appears to be unacceptable because of cracking which will affect the structural integrity as evaluated in the immersion test. (The experiments conducted in this feasibility study do not address the effect of cracking on leaching of contaminants other than $\mathrm{Cr}, \mathrm{Hg}$, and $\mathrm{Cs}$.) No cracking of the direct grout or reference saltstone waste forms was observed for samples cured at $70^{\circ} \mathrm{C}$.

At the present time the implications of waste form cracking at elevated curing temperatures has not been fully addressed. The direct grout falls within the definition of NRC Class $C$ waste. NRC requires that Class $C$ waste forms or their containers demonstrate structural integrity to qualify for disposal. Direct grout cured at $90^{\circ} \mathrm{C}$ will not meet the integrity requirement. However, the disposal vault may meet this requirement. 
WSRC-TR-98-00337

Revision: 0

September 30, 1998

\section{BACKGROUND}

Direct disposal of the cesium in grout is one of the alternatives identified in WSRC-RP98-00166. ${ }^{2}$ In this proposed process, Cs-137 is not separated from the salt waste or concentrated supernate. It is instead sent to the new shielded Saltstone Facility. The resulting waste form would be classified as Class $\mathrm{C}$ low-level waste if disposal was regulated by the NRC. A new grout production facility is needed for this option. The new facility requires remote maintenance capabilities and a shielded cell for the grout production equipment. The test plan for this effort is presented elsewhere. ${ }^{3}$

\section{Comparison of Reference Z-Area Salt Solution and High-Cesium salt Solution} The average composition of the direct grout salt solution is listed in Table 1 and compared to the current reference salt solution composition. The average cesium concentration in the direct grout waste stream is estimated to be $1.65 \mathrm{E}-4 \mathrm{M}(1.5 \mathrm{Ci} / \mathrm{gal}){ }^{4}$ This waste and the resulting direct grout waste form which has about $40 \%$ less curies per volume (about $250 \mathrm{Ci} /$ cubic meter of saltstone) due to dilution with the cementing reagents fall within the NRC Class $\mathrm{C}$ waste category. The Cs-137 concentration limit for Class $C$ waste is 4600 curies per cubic meter. ${ }^{5}$

Table 1. Compositions of the Reference Salt Solution and the Direct Grout, High Cesium Salt Solution. ${ }^{4,6}$

\begin{tabular}{|c|c|c|}
\hline Component & $\begin{array}{l}\text { Reference Salt } \\
\text { Solution } \\
\text { (Molar) }\end{array}$ & $\begin{array}{l}\text { Direct Grout } \\
\text { High Cesium Salt Solution } \\
\text { (Molar) }\end{array}$ \\
\hline $\mathrm{NO}_{3}^{-}$ & 2.04 & 2.49 \\
\hline $\mathrm{NO}_{2}^{-}$ & 0.62 & 0.581 \\
\hline $\mathrm{OH}^{-}$ & 1.17 & 2.181 \\
\hline $\mathrm{CO}_{3}^{-2}$ & 0.15 & 0.181 \\
\hline $\mathrm{AlO}^{-2}$ & 0.41 & 0.355 \\
\hline $\mathrm{SO}_{4}^{-2}$ & 0.15 & 0.169 \\
\hline$F$ & 0.0015 & 0.0361 \\
\hline $\mathrm{Cl}^{-}$ & 0.023 & 0.0282 \\
\hline $\mathrm{C}_{2} \mathrm{O}_{4}^{-2}$ & 0.025 & 0.0136 \\
\hline $\mathrm{PO}_{4}^{-2}$ & 0.01 & 0.009 \\
\hline $\mathrm{Nat}$ & 4.94 & 6.44 \\
\hline $\mathrm{K}^{+}$ & - & 0.0168 \\
\hline $\mathrm{Cs}^{+}$ & $20 \mathrm{n} \mathrm{Ci} / \mathrm{g}$ & 0.000165 \\
\hline $\mathrm{Hg}$ & $0.012 \mathrm{mg} / \mathrm{L}$ & $33 \mathrm{mg} / \mathrm{L}$ \\
\hline$\overline{\mathrm{Cr}}$ & $161 \mathrm{mg} / \mathrm{L}$ & $161 \mathrm{mg} / \mathrm{L}$ \\
\hline
\end{tabular}


WSRC-TR-98-00337

Revision: 0

September 30, 1998

Class C Requirements for Low-Level Waste Disposal ${ }^{7}$

In addition to the minimum requirements for Class $A, B$, and $C$ wastes, $N R C$ has structural stability requirements for Class $\mathrm{B}$ and $\mathrm{C}$ waste. ${ }^{7}$ Stability requires that the waste form maintains its structural integrity under the expected disposal conditions. Structural stability is necessary to inhibit a) slumping, collapse, or other structural failure of the disposal unit if an engineered structure is not used and b) radionuclide release from the waste form that might ensue due to increases in leaching that could be caused by premature disintegration of the waste form. Stability is also considered in the intruder pathways where it is assumed that wastes are recognizable after the active control period. To the extent practical, Class $\mathrm{B}$ and $\mathrm{C}$ waste forms should maintain gross physical properties and identity over a 300 year period. To ensure that Class $B$ and $C$ wastes maintain stability the following conditions should be met:

- The waste should be a solid form or in a container or structure that provides stability after disposal.

- The waste should not contain free standing and/or corrosive liquids.

- The waste or container should be resistant to degradation caused by radiation effects.

- The waste or container should be resistant to biodegradation.

- The waste or container should remain stable under the compressive loads inherent in the disposal environment.

- The waste or container should remain stable if exposed to moisture or water after disposal.

- The as-generated waste should be compatible with the solidification medium or container.

NRC identifies the following tests, which can be used to demonstrate waste form stability:

- Compressive strength; ASTM C-39 (60 psi minimum).

- Resistance to thermal cycling degradation; ASTMB-553.

- Radiation stability at $10 \mathrm{E}+8$ Rads in gamma irradiator or equivalent.

- Resistance to biodegradation; ASTM G-21 and G-22.

- Leach testing; ANS 16.1 (Cs leach index minimum of 6 ).

- Immersion testing, i. e., compressive strength after 90 day immersion period should be 500 psi minimum and not less than $75 \%$ of the pre-immersion compressive strength.

- Free standing liquids (less than 0.5 volume per cent per Method described in Appendix 2 of ANSI/ANS 55.1).

- Full-scale testing. 
WSRC-TR-98-00337

Revision: 0

September 30, 1998

\section{EXPERIMENTAL METHOD $\because-$}

Preparation of the Reference Salt Solution and Direct Grout, High Cesium Salt Solution ${ }^{8}$ Simulated salt solution was made according to the following recipes. Cesium, mercury and chromium were spiked in amounts greater than the concentrations listed in Table 1 in order to determine differences between leaching performance in the various leaching tests. This was necessary given the detection level for non radioactive cesium used in these experiments.

Table 2. Ingredients in the Reference Salt Solution and the Direct Grout, High Cesium Salt Solution.

\begin{tabular}{|c|c|c|}
\hline Ingredient & $\begin{array}{l}\text { Reference Salt } \\
\text { Solution } \\
(\mathrm{g} / \mathrm{L})\end{array}$ & $\begin{array}{c}\text { Direct Grout } \\
\text { High Cesium Salt Solution } \\
(\mathrm{g} / \mathrm{L})\end{array}$ \\
\hline $\mathrm{NaNO}_{3}$ & 173.4 & 211.6 \\
\hline $\mathrm{NaNO}_{2}$ & 43.1 & 40.09 \\
\hline $\mathrm{NaOH}$ & 46.7 & 87.24 \\
\hline $\mathrm{Na}_{2} \mathrm{CO}_{3} \mathrm{H}_{2} \mathrm{O}$ & 18.5 & 22.44 \\
\hline $\mathrm{NaAlO}_{2} \mathrm{H}_{2} \mathrm{O}$ & 40.6 & 34.48 \\
\hline $\mathrm{Na}_{2} \mathrm{SO}_{4}$ & 20.9 & 24.00 \\
\hline $\mathrm{NaF}$ & 0.62 & 1.52 \\
\hline $\mathrm{NaCl}$ & 1.35 & 1.65 \\
\hline $\mathrm{Na}_{2} \mathrm{C}_{2} \mathrm{O}_{4}$ & 3.44 & 1.82 \\
\hline $\mathrm{Na}_{3} \mathrm{PO}_{4}$ & 2.9 & - \\
\hline $\mathrm{Na}_{2} \mathrm{PO}_{4} 12 \mathrm{H}_{2} \mathrm{O}$ & - & 3.42 \\
\hline $\mathrm{KNO}_{3}$ & - & 1.69 \\
\hline $\mathrm{CsNO}_{3}$ & - & $0.643^{*}$ \\
\hline $\mathrm{HgCl}_{2}$ & $0.338^{\star \star}$ & $0.338^{\star \star}$ \\
\hline $\mathrm{Na}_{2} \mathrm{CrO}_{4}$ & 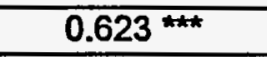 & $0.623^{\star \star \star}$ \\
\hline
\end{tabular}

Cs spiked at $0.0033 \mathrm{M}$ Cs using $\mathrm{CsNO}_{3}$. This is 20 times more than the concentration projected for the direct grout case.

* $\mathrm{Hg}$ spiked at $250 \mathrm{ppm}$ as $\mathrm{HgCl}_{2}$ in direct grout solution prepared for this feasibility study.

**** $\mathrm{Cr}$ spiked at $1830 \mathrm{mg} / \mathrm{L}$ as $\mathrm{Na2CrO} 4$.

Preparation of Reference Saltstone and High Cesium, Direct Grout

The ingredients and proportions in the reference saltstone are shown below:

Cement Type I/II

Fly ash Class F

Slag Grade 120

Salt solution

(containing 71 wt $\%$ water)
4 wt $\%$

25 wt \%

25 wt $\%$

46 wt $\%$
16.

The water to total cementitious solids of this mixture is 0.6048 . 
WSRC-TR-98-00337

Revision: 0

September 30, 1998

The ingredients and proportions used in the direct grout saltstone containing the high cesium loading are shown below. The water to the total cementitious solids ratio is 0.6092 and is similar to that of the reference saltstone.

$\begin{array}{lrl}\text { Cement Type I } & 4 & \text { wt \% } \\ \text { Fly ash Class F } & 24 & \text { wt \% } \\ \text { Slag Grade 120 } & 24 & \text { wt \% } \\ \text { Salt solution } & 48 & \text { wt \% } \\ \text { (containing 66 wt. \% water) } & & \end{array}$

The dry cementitious reagents were premixed to simulate the Z-Area process and then added to the salt solution. Mixing was carried out in a Waring blender for one minute at low speed. Samples were immediately cast into the appropriate containers for the various tests.

\section{Testing}

The approach was to compare the high-cesium, direct grout to reference saltstone with respect to the following properties:

Set time

Bleed water

Processing (flowability of grout -subjective evaluation)

Compressive strength (28 days)

Leaching

TCLP for $\mathrm{Cr}, \mathrm{Hg}, \mathrm{Cs}$

Radiolytic gas generation

Durability Evaluation (limited testing modified ANS 16.1 soak test).

\section{Curing}

The curing was conducted at ambient temperature, $45^{\circ}, 70^{\circ}$ and $90^{\circ} \mathrm{C}+/-5^{\circ} \mathrm{C}$ and $100 \%$ relative humidity. This curing range is representative of the range of initial and long-term curing temperatures which could be encountered under actual field conditions.

\section{Irradiation Experiments}

Two samples of direct grout were cast in cylindrical containers approximately $1 \times 4$ inches in size. These containers were sealed during the 28-day cure period. One sample was cured a $24.5^{\circ} \mathrm{C}$ and the other at $90^{\circ} \mathrm{C}$. The moisture contents of these samples were measured to be 24 and $27 \mathrm{wt}$. \%, respectively. The porosity of each sample was estimated to be 30 to 40 volume percent. These two samples were irradiated simultaneously at a dose rate of $4.2 \mathrm{E}+5 \mathrm{rad} / \mathrm{hour}$ for 185 hours in a Co-60 source. The dose accumulated in the $185 \mathrm{hr}$ irradiation experiment is equivalent to an approximate 34 year dose at a nominal Cs-137 curie loading of $250 \mathrm{Ci} / \mathrm{m}^{3}$. Given the nominal density of the direct grout, $1617 \mathrm{~kg} / \mathrm{m}^{3}$, this corresponds to $7.242 \mathrm{E}-4$ Watts $/ \mathrm{kg}$, or a dose rate of $261 \mathrm{rad} / \mathrm{hr}$. Experimental details pertaining to the Co-60 irradiation, gas analyses, and dose calculations are given elsewhere.? 
WSRC-TR-98-00337

Revision: 0

September 30, 1998

\section{RESULTS AND DISCUSSION :-}

\section{Processibility, Set Time and Bleed Water}

Processibility was evaluated by visual observation. The direct grout slurry was compared to the reference saltstone slurry. The direct grout slurry was easily mixed in the Waring blender. The resulting slurry was fluid and was easily poured into the sample containers. The direct grout gelled (thickened to the extent that it was no longer pourable) in 25 to 30 minutes. The reference saltstone slurry was also very fluid and pourable. However, it gelled in 20 to 25 minutes. Bleed water was not observed on either slurry formulation. Processing results are summarized in Table 3.

Table 3. Processing results for Reference Saltstone and Direct Grout.

\begin{tabular}{|l|c|c|c|c|}
\hline Mix Design & $\begin{array}{l}\text { Qualitative Flow } \\
\text { Properties }\end{array}$ & $\begin{array}{l}\text { Gel Time } \\
\text { (minutes) }\end{array}$ & $\begin{array}{l}\text { Bleed Water } \\
\text { (volume \%) }\end{array}$ & $\begin{array}{l}\text { Set Time } \\
\text { (hours) }\end{array}$ \\
\hline $\begin{array}{l}\text { Reference } \\
\text { Saltstone }\end{array}$ & $\begin{array}{c}\text { Very Fluid, } \\
\text { Pourable }\end{array}$ & $20-25$ & 0 & $18-24$ \\
\hline Direct Grout & $\begin{array}{c}\text { Very Fluid, } \\
\text { Pourable }\end{array}$ & $25-30$ & 0 & $18-24$ \\
\hline
\end{tabular}

\section{Compressive Strength}

Compressive strength was determined for samples cured for 28 days at $24.5,45,70$, and $90^{\circ} \mathrm{C}$. The relative humidity of all of the samples except those cured at $90^{\circ} \mathrm{C}$ was maintained at $100 \%$. The samples cured at $90^{\circ} \mathrm{C}$ were cured in the presence of excess water/water vapor. However, cracks were observed on these samples when they were removed from the curing chamber. See Figure 1. These samples also appeared dry on the outer surface. This was confirmed when the samples were examined after the compressive strength tests. The outer centimeter of the samples was obviously drier than the inner core.

Consequently the $90^{\circ} \mathrm{C}$ samples experienced some drying. Drying shrinkage is probably not the only explanation for the observed cracks since other samples cured at $90^{\circ} \mathrm{C}$ in sealed containers showed no drying and were also found to be cracked after curing.

- Even though the direct grout and reference saltstone $90^{\circ} \mathrm{C}$ samples were cracked prior to the strength determinations the strengths were very high. Given the limited number of samples tested, the strengths of the direct grout and reference saltstone are similar for each curing temperature. Compressive strength results are summarized in Table 4. 


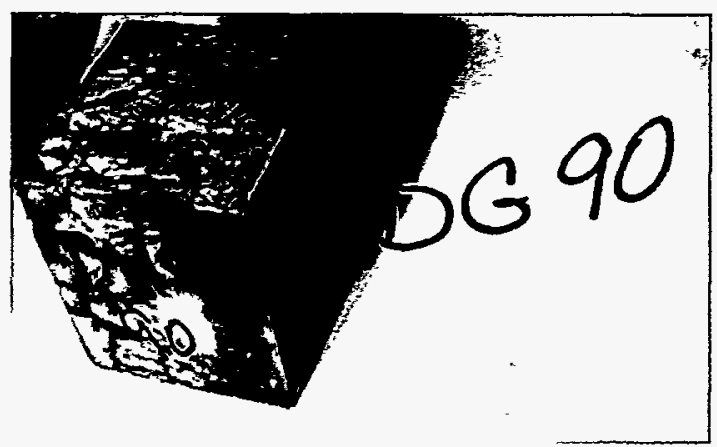

Figure 1. Photographs Illustrating the Crack Patterns Characteristic of Reference and Direct-Grout Sample Cured at $90^{\circ} \mathrm{C}$ (No cracking was observed for samples cured Between Room Temp. and $70^{\circ} \mathrm{C}$ ).

Table 4. Compressive Strength Results for Direct Grout and Reference Saltstone

\begin{tabular}{|c|c|c|c|}
\hline Mix Design & $\begin{array}{c}\text { Curing } \\
\text { Temperature } \\
\left({ }^{0} \mathrm{C}\right)\end{array}$ & $\begin{array}{c}\text { Compressive } \\
\text { Strength } \\
\text { (psi) }\end{array}$ & $\begin{array}{c}\text { Average } \\
\text { Compressive } \\
\text { Strength (psi) }\end{array}$ \\
\hline \multirow{8}{*}{ Direct Grout } & \multirow[b]{2}{*}{24.5} & 2,050 & \multirow[b]{2}{*}{2,212} \\
\hline & & 2,375 & \\
\hline & \multirow[b]{2}{*}{45} & 4,000 & \multirow[b]{2}{*}{4,075} \\
\hline & & 4,150 & \\
\hline & \multirow[b]{2}{*}{70} & 3,250 & \multirow[b]{2}{*}{3,412} \\
\hline & & 3,575 & \\
\hline & \multirow[b]{2}{*}{90} & 4,675 & \multirow[b]{2}{*}{4,562} \\
\hline & & 4,450 & \\
\hline \multirow{8}{*}{$\begin{array}{l}\text { Reference } \\
\text { Saltstone }\end{array}$} & \multirow[b]{2}{*}{24.5} & 2,225 & \multirow[b]{2}{*}{2,325} \\
\hline & & 2,425 & \\
\hline & \multirow[b]{2}{*}{45} & 3,575 & \multirow[b]{2}{*}{3,525} \\
\hline & & 3,475 & \\
\hline & \multirow[b]{2}{*}{70} & 3,875 & \multirow[b]{2}{*}{3,675} \\
\hline & & 3,475 & \\
\hline & \multirow[b]{2}{*}{90} & 4,250 & \multirow[b]{2}{*}{3,925} \\
\hline & & 3,600 & \\
\hline
\end{tabular}


WSRC-TR-98-00337

Revision: 0

September 30, 1998

\section{Leaching}

TCLP

Samples were prepared for TCLP testing for $\mathrm{Cr}$ and $\mathrm{Hg}$, which are the two potentially hazardous constituents in both the high cesium (direct grout) and reference salt solutions. All samples of reference saltstone and direct grout cured between 24 and $90^{\circ} \mathrm{C}$ passed the TCLP for $\mathrm{Cr}$ and $\mathrm{Hg}$. Consequently, these waste forms qualify to exit RCRA.

The TCLP extract was also analyzed for Cs to give a relative comparison of the Cs leachability for the two formulations. The direct grout samples were spiked with about 20 times more cesium than is actually expected $(1.5 \mathrm{Ci} / \mathrm{gal} \mathrm{Cs}-137)$ to assure detection above the reportable limit in the TCLP extracts since the objective was to evaluate the effect of curing temperature on cesium leachability. Based on the total cesium concentration in the direct grout samples $(150 \mathrm{ug} / \mathrm{g}$ ) between 11 and $16 \%$ of the cesium was leached during the 18 hour TCLP test on crushed samples. This is consistent with the limited retention of cesium in the reference saltstone as modeled in the Z-Area performance assessment $\left(\mathrm{K}_{d}=2\right.$ for $\left.\mathrm{Cs}\right){ }^{10}$

Table 5. TCLP Results for Direct Grout and Reference Saltstone Cured between 24 and $90^{\circ} \mathrm{C}$.

\begin{tabular}{|c|c|c|c|c|c|}
\hline \multirow{2}{*}{$\begin{array}{l}\text { Sample } \\
\text { Description }\end{array}$} & \multirow[t]{2}{*}{ Sample ID } & \multirow{2}{*}{$\begin{array}{l}\text { Curing } \\
\text { Temperature } \\
\left({ }^{\circ} \mathrm{C}\right)\end{array}$} & \multicolumn{3}{|c|}{ TCLP Results } \\
\hline & & & $\begin{array}{c}\mathrm{Cr} \\
(\mathrm{ug} / \mathrm{L})\end{array}$ & $\underset{(\mathrm{mg} / \mathrm{L})}{\mathrm{Hg}}$ & $\begin{array}{c}\text { Cs } \\
(\operatorname{ug} / \mathrm{x})\end{array}$ \\
\hline \multirow{4}{*}{$\begin{array}{l}\text { Reference } \\
\text { Saltstone }\end{array}$} & $980072 \mathrm{~A}$ & 24.5 & $<60$ & $<0.020$ & $<40$ \\
\hline & $98 \mathrm{~L} 45 \mathrm{~B}$ & 45 & $<60$ & $<0.020$ & $<40$ \\
\hline & $980067 \mathrm{~A}$ & 70 & $<60$ & $<0.020$ & $<40$ \\
\hline & $980066 \mathrm{~A}$ & 90 & $<60$ & $<0.020$ & $<40$ \\
\hline \multirow{4}{*}{ Direct Grout } & $980071 \mathrm{~A}$ & 24.5 & $<60$ & $<0.020$ & 1150 \\
\hline & 98SLA5A & 45 & $<60$ & $<0.020$ & 932 \\
\hline & 980068A & 70 & $<60$ & $<0.020$ & 807 \\
\hline & $980069 A$ & 90 & $<60$ & $<0.020$ & 882 \\
\hline $\begin{array}{l}\text { TCLP } \\
\text { Regulatory } \\
\text { Limit* }\end{array}$ & & & $\begin{array}{c}5000 \\
(5 \mathrm{mg} / \mathrm{L})\end{array}$ & 0.2 & NA \\
\hline
\end{tabular}

* Limit for disposal of treated characteristic waste.

\section{Radiolytic Gas Generation}

Two samples (approximately $65 \mathrm{~g} \mathrm{each}$ ) of direct grout were irradiated in an air sealed systems containing approximately $55 \mathrm{cc}$ of air. Details of the experimental configuration are given elsewhere. ${ }^{8}$ Preliminary analysis of the gas collected above the irradiated direct grout samples indicates that hydrogen was produced with a $\mathrm{G}$ value of 0.02 to 0.03 molecules per $100 \mathrm{eV}$. These $\mathrm{G}$ values are based on the total mass of grout irradiated 
WSRC-TR-98-00337

Revision: 0

September 30, 1998

(grout plus moisture). Given a nominal moisture content of about $25 \mathrm{wt} \%$, a $\mathrm{G}\left(\mathrm{H}_{2}\right)$ based on water alone was calculated to be in the range of 0.08 to 0.12 . These $\mathrm{G}$ values are significantly lower than the maximum value obtained from pure water, 0.45 . Similar results were obtained for dry CST powder irradiation experiments. ${ }^{8}$

Hydrogen concentrations in air of $4 \%$ or more constitute a flammable mixture. Assuming that the direct grout disposed of in the new saltstone vaults will not constitute a closed system (the grout and the concrete vault have open, interconnected porosity), the radiolytic gas production is not expected to result in accumulation of hydrogen in the pores of the saltstone or the air void spaces in the vault.

In addition, visual observation of the samples after irradiation to a 34 year dose indicated no degradation or cracking. However, a difference in the gas pressure versus irradiation time profiles was observed for the direct grout samples cured at $24^{\circ}$ and $90^{\circ} \mathrm{C}$. Direct grout cured at $24^{\circ}$. C showed a linear increase in pressure as a function of irradiation time. $A G$ value for the total gas produced was similar to the $G$ value for hydrogen ( 0.01 and 0.02 , respectively). Direct grout cured at $90^{\circ} \mathrm{C}$ showed an initial depressurization followed by a linear increase in pressure. This is similar to the profile observed with CST irradiation. ${ }^{9}$ Although the $\mathrm{G}\left(\mathrm{H}_{2}\right)$ was similar for the two samples, the sample cured at $90^{\circ} \mathrm{C}$ resulted in more total gas generation. A G value for the total gas produced was higher than the $G$ value for hydrogen ( 0.07 and 0.03 , respectively). This indicates that there was radiolytic production of gas other than hydrogen in the direct grout sample cured at $90^{\circ} \mathrm{C}$.

\section{Phase Determination}

$X$-ray diffraction analyses of specimens cured over the entire temperature range indicate the presence of poorly crystalline hydrotalcite, a hydrated magnesium silicate phase characteristic of hydrated slag systems. Gypsum, a hydrated calcium sulfate phase was also detected in all of the samples. The current analysis did not indicate any phase differences over the temperature range studied.

\section{Immersion Test (Durability/Integrity Evaluation)}

An immersion test to evaluate structural integrity is in progress. Samples cured at 24.5, 45,70 and $90^{\circ} \mathrm{C}$ are currently immersed in deionized water. These samples will be soaked for 90 days and then the compressive strength will be measured. To date, the only type of data available are the result of visual observations. Cracking was observed in the samples cured at $90^{\circ} \mathrm{C}$ at the time the samples were removed from the molds. Samples cured at $70^{\circ} \mathrm{C}$ and lower did not show any signs of cracking. See Figure 2. All of these samples were cured in sealed containers and did not experience significant drying. Consequently, the cracking observed in the direct grout and reference saltstone samples cured at $90^{\circ} \mathrm{C}$ is probably caused by a mechanism other than external drying. Crystallization of soluble or insoluble phases within the matricies of these samples is one possible explanation. However, additional studies are required to understand the cause of the cracking. 
WSRC-TR-98-00337

Revision: 0

September 30, 1998
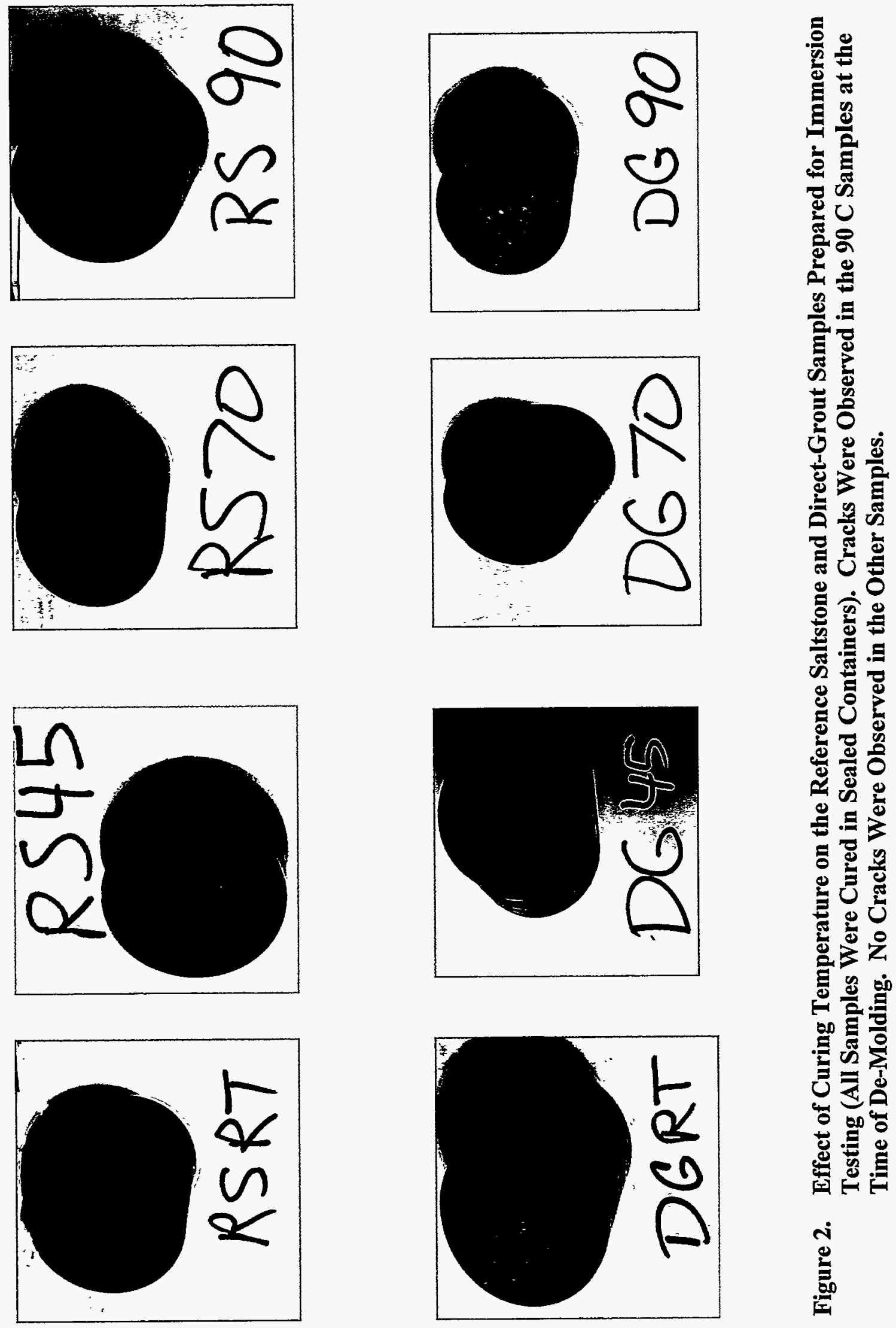
WSRC-TR-98-00337

Revision: 0

September 30, 1998

\section{CONCLUSIONS}

Salt solution containing up to $6.4 \mathrm{M}$ sodium salts and an average Cs- 137 concentration of $1.5 \mathrm{Ci} / \mathrm{gal}$ can be stabilized in a saltstone waste form. Based on the results of this feasibility study and the current understanding of the effect of curing temperatures on long term properties, no formulation change is required. This statement assumes that pouring strategies, ${ }^{1}$ raw materials temperatures and specifications, and Cs-137 and other radionuclide concentrations will be managed to maintain curing temperatures below $90^{\circ} \mathrm{C}$. Based on the data available to date, the temperature threshold for cracking is between 70 and $90^{\circ} \mathrm{C}$.

Direct grout made from $6.4 \mathrm{M}$ sodium salt solution containing 1830 and $250 \mathrm{mg} / \mathrm{L}$ of $\mathrm{Cr}$ and $\mathrm{Hg}$, respectively, were determined to be non hazardous based on the TCLP test. The direct grout saltstone has processing properties similar to those of the current saltstone waste form (except for the additional shielding and remote handling required for the higher activity in the high cesium waste).

Based on results obtained in this feasibility study, hydrogen gas generation due to radiolysis of the free water in the saltstone will not result in the accumulation of hydrogen above the explosive limit since the waste form is monolithic and there is no void space inside the closed vaults. In addition, migration of hydrogen gas through the waste form pore spaces is not expected to damage the microstructure of the saltstone since the pore space is interconnected.

Most of the cracking observed in samples cured at $90^{\circ} \mathrm{C}$ is attributed to drying shrinkage due to water evaporation. However, at least one other mechanism may be present since samples cured in sealed containers also cracked (too a lesser degree). The compressive strengths of the direct grout and reference saltstone cured at $90^{\circ} \mathrm{C}$ were high in spite of the cracking observed in the samples. This indicates that although the cracks were formed, they did not open. However, the cracks in the $90^{\circ} \mathrm{C}$ samples are opening in the immersion test, which requires a 90-day soak in deionized water. Depending on the results of this test, the direct grout and reference saltstone cured at $90^{\circ} \mathrm{C}$ for long term $(28$ days) may not pass the immersion test which is intended to indicate structural integrity/durability. In the present analysis, there are two options for addressing the results of the immersion test, 1) cure direct grout and saltstone below $90^{\circ} \mathrm{C}$ (samples cured at $70^{\circ} \mathrm{C}$ showed no cracking) or 2) take credit for the structural integrity of the vault (waste form container). 
WSRC-TR-98-00337

Revision: 0

September 30, 1998

\section{RECOMMENDATIONS}

Long-term curing experiments of reference saltstone and direct grout as a function of curing temperature are recommended if direct disposal of grout is selected as the preferred or backup technology to replace the current ITP process. This recommendation is consistent with the direct grout feasibility evaluation and the SRTC technical program evaluation conducted by BNFL. (See Attachment for the BNFL comments.)

Leaching experiments on direct grout cured over the temperature range 24 to $90^{\circ} \mathrm{C}$ is also recommended.

Additional irradiation and gas collection/analysis experiments should be conducted to further investigate the affect of curing temperature on the direct grout performance.

Regulatory and performance requirements for direct grout should be determined.

Production and pouring strategies should be developed to meet the regulatory and performance requirements.

Tests should be conducted to determine the effect of changes in the salt composition on the properties of the direct grout in order to establish acceptable operating ranges.

Based on the results of this feasibility study, the current saltstone formulation range is adequate for the direct grout. However, if the short term curing temperature cannot be managed by applying a multi-cell pour strategy, then substituting granulated slag for Grade 120 slag should be evaluated. The simplest way to control the long term curing temperature is to adjust the curie content of the waste/waste form if long-term curing is an issue.

\section{QUALTTY ASSURANCE}

Results are recorded in WSRC-NB-98-00204. Testing was conducted in accordance with SRTC procedures. 
WSRC-TR-98-00337

Revision: 0

September 30, 1998

\section{REFERENCES}

1. A. Shadday, "Thermal Modeling of the Saltstone Pouring and Curing Process," (U), M-CLC-A-00144, 9-22-98.

2. P. L. Rutland, et al., "Bases, Assumptions, and Results of the Flowsheet Calculations for the Initial Eighteen Salt Disposition Alternatives," WSRC-RP-98-00166, June 15, 1998.

3. C. A. Langton, "Phase IV Test Plan for Direct Grout" (U), SRT-WED-98-0114, 8-31-98.

4. D. D. Walker, E-Mail correspondence, 7-27-98.

5. CFR Part 61.55.

6. D. D. Walker, E-Mail correspondence, 7-29-98.

7. CFR Part 61.56.

8. D. D. Walker, E-Mail correspondence, 9-24-98.

9. N. E. Bibler and C. L. Crawford, and C. R. Biddle, "Results of Scoping Studies for Determining Radiolytic Hydrogen Production form Moist CST and CST Slurries," WSRC-RP-98-01143, 10-2-98.

10. Martin Marietta Energy Systems, Inc., "Radiological Performance Assessment for the Z-Area Saltstone Disposal Facility" (U), WSRC-RP-92-1360, 12-18-92.

\section{ACKNOWLEDGEMENTS}

D. D. Walker, SRTC, and J. R. Fowler provided the high-cesium salt waste composition used to prepare the direct grout formulation.

C. Crawford and N. Bibler, and C. Biddle, SRTC/TTS, conducted irradiation experiments and provided the analysis to the gas generation rate.

L. Tovo, SRTC/ADS, and B. T. Butcher, SRTC/WPT expedited analytical analyses. 
WSRC-TR-98-00337

Revision: 0

September 30, 1998

\section{ATTACHMENT I}

BNFL Response to Questions and SRTC Program Review 


\section{Memorandum}

To: SRTC

From: Graham Jonssou

Ext: +441946772477

Fax: +441946772490
Date: 22 September 1998

Your ref:

Our net: CEMlas|s 1065

Subjoct: Saltstone Immobilisation Programme

Tó all at SRTC

\section{SALTSTONE IMMOBIIISATION PROGRAMME}

This note details comments made by BNFL regarding initial questions raised by SRTC. With respect to the Saltstone immobilisation progtamme (Section 1), and then in Section 2 a review of the proposed SRTC development programme is given.

\section{SECTION 1}

Q1:Does the Saltstone formalation require changing besed on the inclusion of the Cs in order to mcet TCLP requirements ?

Al:The inclusion of $\mathrm{Cs}$ into the wasteform on it's own should not affect the leachability of the metals in the TCLP test. Given that the TCLP test would be performed after 28 days, it is very unlikely that the higher overall temperature of the Saltstone monolith will have any effect on metal solubilities. However the longer term effects of the elevated temperatures on metal retention within the system should be part of the forward programme as it is outside of the current scope of experience.

Although this is different to the TCLP test (i.e. a test that is undertaken after 28 days) it is none the less important that the chemistry of the system is understood to predict longer term behaviour. It is also important to realise that in the TCLP test, the sample is actually ground and therefore monolithicity is not a factor. It is the actual effects of heat upon the overall cement system that is the major point to establish.

W.

Q2:If the formulation does need changing to meet TCLP would this be adequate, or would an alternative additive be required? 
A2 : As stated in Answer 1 it is not certain how the microstructure will be affected by being exposed to high temperatures (greater than $80^{\circ} \mathrm{C}$ ) over extended periods of time. It is not considered that the ability to comply with the TCLP requirements will be affected. If overall radiogenic heat is seen as problematic the simplest altemative may be to just limit the amount of Cs present in the waste. Altematively different cement systems can be evaluated for suitability.

Q3: What would the bulk temperature rise to based on the heat of hydration , and would the pouring volume need to be limited because of this?

A3:Information provided by SRTC is now being used by modellers to predict the bulk temperature rise. .

Q4: What effect will the higher Cs loading have on the bulk temperatures in the long term?

A.4: The Cs loading will govem the bulk temperature within the matrix, with overall tempertaure inoreasing as the Cs loading increases. Initial results from modelling experiments at SRTC indicate that the bulk temperatures will be around $90^{\circ} \mathrm{C}$. This can be substantiated by additional modelling studies in the U.K.

Q5:If curing heat or radiolytic heat is a concern how would we addiress?

A5:This can be done by limiting the amount of $\mathrm{Cs}$ within the product, changing the cement formulation or considering an alternative matrix.

Q6:Will gas generation be a concern and if so how will it be addressed ?

A6: The porosity and permeability of the cement microstructure will be sufficient to deal with gas generated from any associated reactions. However this will need to be checked during the development programme to establish the effects at the elevated temperatures.

Q7: What tests would be required to demonstrate short and longer term gas generation will not be a problem?

A7: The sample will need to be exposed to the expected radiation dose that it would need to withstand in order to retain product integrity. Whereas in the U.X. wasteforms are exposed to the cumulative dose that they would experience during up to 100 years' storage and disposal, the actual dose that the Saltstone wasteform will need to withstand will be specific to the waste acceptance criteria (WAC) goveraing disposal. 


\section{Section 2 : Proposed SRTC development programme}

Set :

This is normally undertaken to establish-throughput requirements for batch plants. As the proposed process is continuous mixing followed by pumping and placement, setting is only important if severe retardation is observed, or if set is achieved too quickly. The latter point may be particularly important if the mix were to be delayed on line to the disposal facility. This could result in blocked pipework and the inherent problems of dealing with remediation where the radiation levels will be significantly higher for manual intervention.

Time of set will also need to be established during the pouring stage to establish the effects of pouring additional cemented products on material that may have only undergonc partial setting. This can lead to cracking and loss of product integrity.

\section{Hleed water :}

Again bleed water is nomally associated with plant throughput requirements, although the avoidance of the generation of secondary wastes is also of major impontance. Ideally the formulation should provide a bleed free product, however at what time bleed water must not be present will be very specific to this particular project.

\section{Processing :}

The proposal is to have a subjective test. Experience in the U.K. indicates that this kind of evaluation is not suitable, and it is suggested that actual methods to evaluate grout processability / fluidity are established.

\section{Compressive strength :}

While the test indicates that the test will be undertaken after 28 days, it is recommended that a strength development profile is undertaken. This will allow a prediction to be made of any potential interactions taking place within the matrix. It may also be beneficial to undertake these measurements over longer periods so that the longer term strength development profile can be monitored.

There are also non-destructive tests that can be performed to monitor strength development as opposed to compressive strength.

\section{Leaching :}

The standard test is to undertake the TCLP test after 28 days. It is recommended that additional testing is undertaken to establish any likely affects of the higher heat loading on the overall cement microotructure.

\section{Radiolytic gaslgeneration:}

The wasteform needs to be exposed to the cumulative radiation dose that the wasteform will experience during the evaluation period. This will not only establish the effects of radiation on the wasteform stability, but can also, bc used to establish the effects (if any) of dealing with any gas generated upon the cement microstructure. 
The curing temperatures will need to reflect the actual core temperatures which the matrix will experience and therefore any tests will need to be able to reflect thesc temperatures as opposed to simply curing at the temperature under assessment.

\section{General comments:}

The overall programme is focussed mainly on passing the necessary WAC. However as this * wastestream composition is now fundamentally different to the original Saltstone, it is considered that additional testing would be beneficial in understanding the ongoing cement/waste interactions taking place.

The programme does not indicate any timescales for the test period.

The surrogate needs to be prepared in as near as possible the same way as the waste will be produced during future operations.

The programme appears to be focussed upon dealing with a worst case scenario. It may be beneficial to consider a range of formulations to understand any changes occurring as formulations change.

In terms of the actual process, I have assumed that the relevant operating envelopes and equipment deployed and established for the original plant will still be used in the new facility and are therefore outside the scope of these comments.

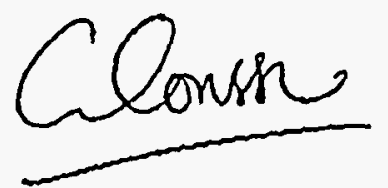

\section{GH Jonsson}

Research and Technology

Sellafield

Seascale

Cumbria. 
WSRC-TR-98-00337

Revision: 0

September 30, 1998

WESTINGHOUSE SAVANNAH RIVER COMPANY

SAVANNAH RIVER TECHNOLOGY CENTER

March 30, 1998

Distribution:

G. Abell, 704-3N

P. C. Suggs, 704-3N

J. L. Barnes, 704-3N

W. L. Tamosaitis, 773-A

S. B. Beck, 704-3N

D. D. Walker, 773A

B. T. Butcher, 773-43A

J. Watson, 704-3N

J. D. Carlson, 703-H

G. T. Wright, 773-A

R. A. Dimenna, 773-42A

J. T. Carter, 703-25S

N. R. Davis, 703-H

H. H. Elder, 704-S

S. D. Fink, 773-A

J. R. Fowler, 704-3N

M. W. Geetings, 773-24A

T. Hang, 773-42A

P. Hudson, 704-3N

R. A. Jacobs, 704-3N

M. D. Johnson, 703-H

M. T. Keefer, 241-153H

P. S. Kirkland, 703-46A

G. Kosiancic, 704-3N

B. L. Lewis, 703-H

T. J. Lex, 703-H

J. W. McCollough, 703-H

M. S. Miller, 704-56H.

T. M. Monahon, 703-H

J. P. Morin, 703-H

E. Murphy, 704-3N

L. M. Nelson, 773-43A

L. Papouchado, 773-A

P. K. Paul, 773-43A

R. A. Peterson, 773-A

S. F. Piccolo, 704-3N

K. J. Rueter, 706-S

P. L. Rutland, 704-196N

W. E. Stevens, 773-A 